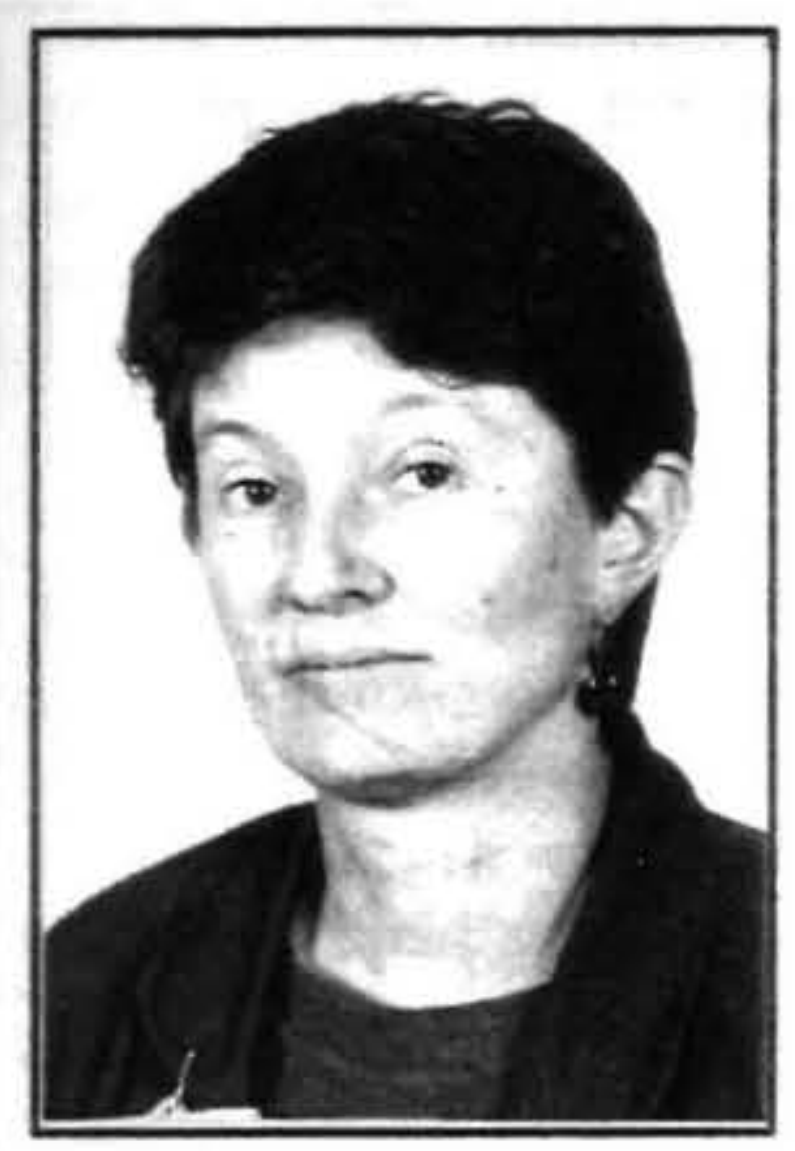

\title{
THEORIES OF CORPORATISM: A FEMINIST CRITIQUE
}

\author{
Linda Hill \\ Canterbury University
}

\begin{abstract}
Political theories of corporatism from the late 1970s make turgid reading and rather deservedly disappeared down a theoretical rabbit hole. However, my doctoral thesis on Feminism and Unionism draws on that theoretical framework as well as socialist feminist theories to think about recent radical change in New Zealand labour relations. This paper outlines corporatist theories, looks at how these featured in some union/political thinking in New Zealand in the late 1980 s, and why, even though they are useful, they are inadequate to explain the labour market situation of New Zealand women and their unions.
\end{abstract}

The shift from occupational awards to enterprise or individual contracts under the Employment Contracts Act 1991 represents a radical change in the pattern of corporatism between 'capital', 'labour' and 'the state' in New Zealand. Political theories of corporatism (Schmitter \& Lehmbruch 1979; Lehmbruch \& Schmitter 1982; Jessop 1979) provide a framework for considering bargaining 'reform' under National, and also the Compact between the NZ Council of Trade Unions (NZCTU) and the previousLabour govermment(ACTU/TDU 1987; NZCTU 1988, 1989).

Labour relations legislation reflects the shifting interests and balance of power between the corporatist partners. However, 'labour' is not a single abstract entity but comprises women and men at work in very difficult situations in the labour market. I argue here that corporatist theory and corporatist strategies are gender blind, but not gender neutral. Nevertheless, corporatist theory offers a framework for reviewing the change to enterprise contracts with regard to the collective bargaining power of women.

\section{Theorising Corporatism}

Corporatism was developed as a concept in political theory in the 1970s as part of ideal typologies of political representation and political economy (Jessop 1979:186-189). It refers to the institutionalisation of interest representation in exchange for state intervention. Corporatist arrangements enable organisations representing capital and labour to participate in the 'authoritative' formulation of policy for the economy and society as a whole (Wassenberg 1982:95). In return they submit to varying degrees of state regulation, particularly of bargaining between organised labour and employers.

Corporatism is often seen as a strategy of the state (rather than of capital or labour) aimed at 'unity, order. nationalism and success' (Jessop 1979:186), though these might equally be goals of state policy in egalitarian Sweden or fascist Italy (Regini 1982:109). Discussions which focus on the political management of economic and social issues (Lehmbruch \& Schmitter 1982:26) have tended to:

...treat the state as an autonomous subject...able to impose its own goals on the economic order...to conflate the growth of state support for private capital with state control over private capital and nullif(y) the specificity of the corporatlst form of state. (Jessop 1979:189-190)

Corporatist theorising provided a framework for comparisons between social democracies (Schmitter \& Lehmbruch 1979; Lehmbruch \& Schmitter 1982). Studies were often ahistorical, focused on conformity to a universal model (Rubery 1988:254) which could take on a prescriptive, almost Darwinian dimension, with Sweden as the most advanced example of corporatist development. This tendency can be detected in the 'strategic unionism' of the NZ Council of Trade Unions and Australian CTU (ACTU/ TDC 1987: NZCTU 1988, 1989; Harvey 1992), discussed later.

In analysing change, corporatism may be seen, not as the amount of state intervention, but as the manner in which the state is articulated with the economic order (Jessop 1979:188). In a political economy view, corporatist patterns are politically and historically contingent arrange- 

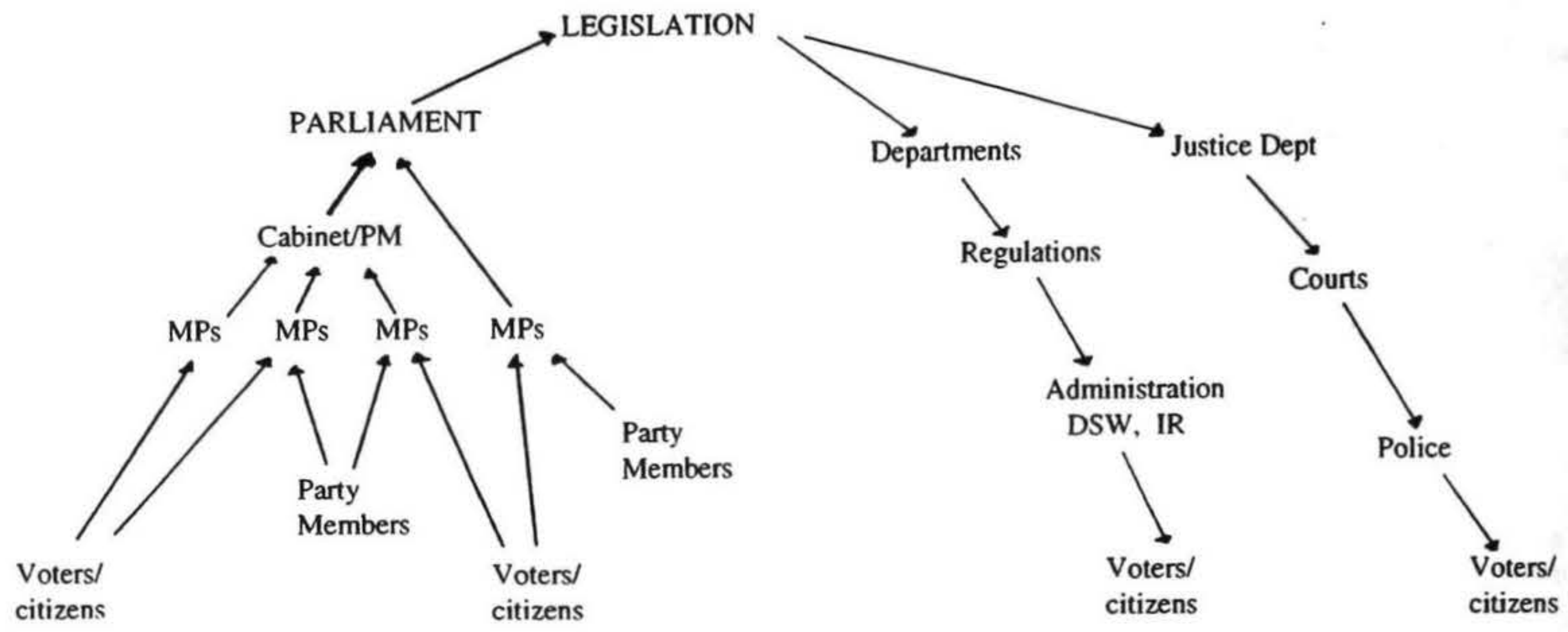

ments resulting from 'the balance of political forces mediated through state forms' (Jessop 1979: 210). Since political outcomes are never static nor permanent, no particular corporatist arrangement should be privileged theoretically. Preferences reflect political interests.

Bob Jessop (1982:193-6) discusses parliamentarism and corporatism as two distinct modes of formal articulation between representation and intervention (figures 1 and 2). Corporatism involves representation of members (workers or employers) within public 'corporations' (unions or employers' associations) constituted around the division of labour, fused with state intervention through these same corporations to regulate members. Unions both represent members' collective bargaining power and bind them to collective agreements; they are confining as well as enabling institutions. A parallel situation exists within national organisationsrepresenting employers(Vowles 1985; Brosnan, Walsh \& Rowe 1985; Taylor \& Greenslade 1986; Wanna 1989) (figure 2). State regulation of negotiations between the two provides governments with the opportunity to protect their own interests, both indirectly and through agreements or intervention.

The pattern of representation and intervention at the heart of corporatism does not presuppose the forms of organisa-

\section{Figure 2. Corporations of interest representation and control - idealised}

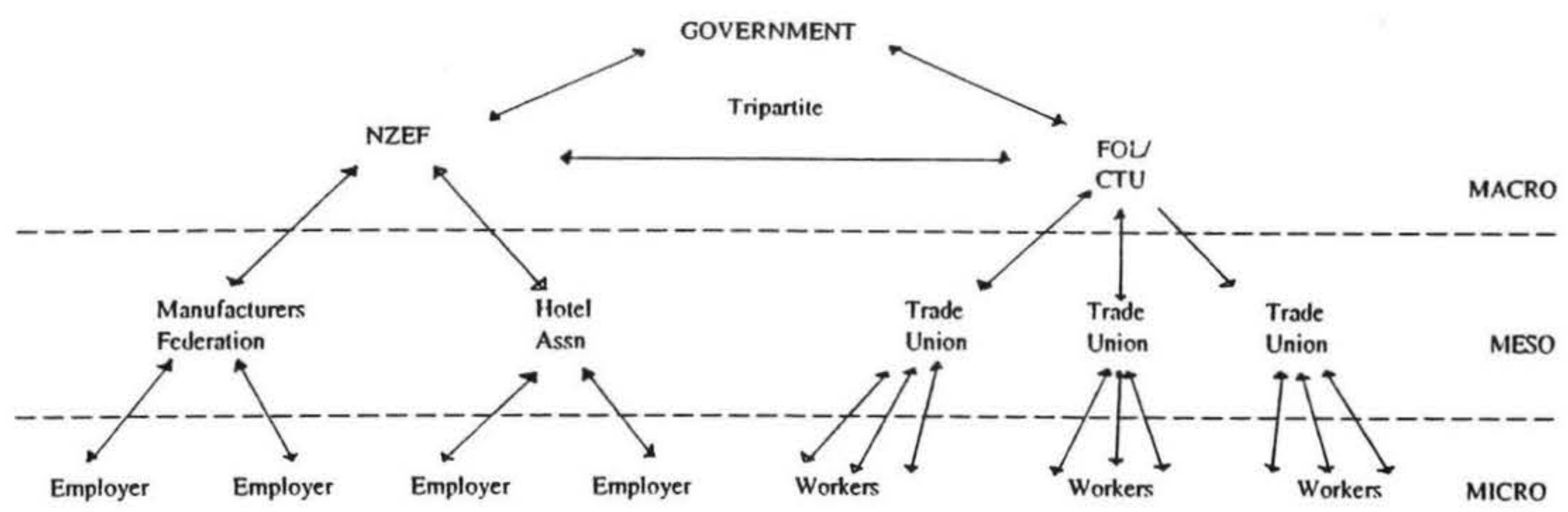


tion or levels of hierarchy at which corporatist interaction is institutionalised. Patterns are historically and culturally specific and subject to change, reflecting in the changing interests of 'capital', 'labour' and 'the state', as well as their differing power and material resources to pursue those interests.

Although use of the term 'corporatism' is often intended to mean used formal negotiations between national leaders, interaction between 'corporations' may be institutionalised at different levels. Arthur Wassenberg's (1982) analysis of this is particularly relevant to the changing situation in New Zealand. Interaction between the hierarchically organised organisations of labour and capital occurs at the 'micro' level of employees and employer, at the meso level of unions and employers, perhaps locally or regionally: and at the 'macro' level of national leaders. Wassenberg considers that corporatism, as industrial struggle by other means, is a device which may displace inherent conflicts of interest between labour and capital rather than resolve them. Apparent resolution - or institutionalised control - at one level may displace dissatisfaction or conflict to other levels. In his view:

As long as the macro stage can be used for acts of symbolic polarisation...(and) micro stages continue to be beset by direct class confrontation, the meso level seems to become more and more the appropriate place for striking a bargain without too much publicity and without too much transparency concerning the exact share of responsibilities for the final outcome (Wassenberg 1982:85).

Arthur Wassenberg was discussing European unions organised by industry rather occupation. However, this statement could describe labour relations in New Zealand and Australia where relations between labour and capital have traditionally been institutionalised at the meso level (figure 3).

\section{Meso Corporatism in New Zealand}

In New Zealand corporatism has traditionally operated at the meso level of unions and groups of employers through the state arbitration of wage awards. This system has been described as an 'historic compromise' between 'labour', 'capital' and 'the state' (Holt 1986; Jesson 1987; Simpson 1991). A state-registered document was settled between the union with registered coverage of a particular labour market and representatives of interested employers. An award document set legally enforceable minimum wage rates and conditions for the occupations described in it and was legally enforceable on all employers who employed such workers. From 1936 various forms of compulsory union membership helped extend this system to industrially weak groups of workers - particularly female dominated occupations - which had often it difficult to organise successfully.

This centralised wage bargaining required little member- ship participation. As long as prosperity was shared through annual increases in award rates, meso level bargaining did not require organisation or action at the 'micro' level of the workplace. In Wassenberg's(1982:85) phrase, the memberships of many unions remained 'anaethetised'. At the macro level Federation of Labour leaders interacted informally with business and political leaders, representing the viewpoint of 'the unions' (Skinner 1980; Vowles 1985: 226). However, affiliated unions enjoyed considerable autonomy.

The Arbitration Court was 'a political institution' (Brosnan, Smith \& Walsh 1990:32) in that it was a site for negotiation, conciliation and arbitration between representatives of labour and capital, before a panel of Commissioners comprised of nominees of labour, capital and the state. It was constituted within a body of law recognising the inherent inequality of the 'master-servant' relationship rather than law governing civil contracts between presumed equals (Mulgan 1993; Ryan \& Walsh 1993). Though at different times its rulings were considered unsatisfactory by some or all three of the corporatist partners, they were pragmatic solutions, as much as legal ones, aimed at meeting the expectations of unions, employers and governments.

Meso level corporatism was a package deal through which wage bargaining was both supported and controlled. Access to arbitration and compulsory union membership were traded against unions' right to strike. However, this package was not static, but reflected the changing interests of 'capital' 'labour' and 'the state' (Holt 1986). Through the 1970s and 1980s successive legislation introduced the option of direct bargaining, changed the form of compulsory unionism and arbitration and widened the narrow range of 'industrial issues'.

As the interests of capital became more hegemonic in government policies (Oliver 1989; Goldfinch \& Roper 1993; Roper 1993), traditional bargaining arrangements at the meso-level were dismantled. The Employment Contracts Act. 1991 shifted the basis bargaining from the occupation to the enterprise or individual. Negotiations for collective enterprise contracts - but not multi-employer contracts - could be supported by strike action but the court could only rule on legality and breech of contracts, once negotiated.

The loss of meso level multi-employer bargaining displaced conflict to the micro level of worksite disputes and individual grievances. Although individual rights were extended (Boxall 1991:292; Walsh 1993:190), many workers in small firms have been unable to bargain at a meaningful level of collectivity. Any macro-level solution to this will require a displacement of labour relations conflict to parallel party political and parliamentary arenas from which the Employment Contracts Act resulted.

This outlines in the abstract and gender-blind language of corporatist theory the shifting political interests and chang- 


\section{Figure 3. Corporatism a la Jessop, 1979 \& Wissenstein, 1982 - interest representation and control}

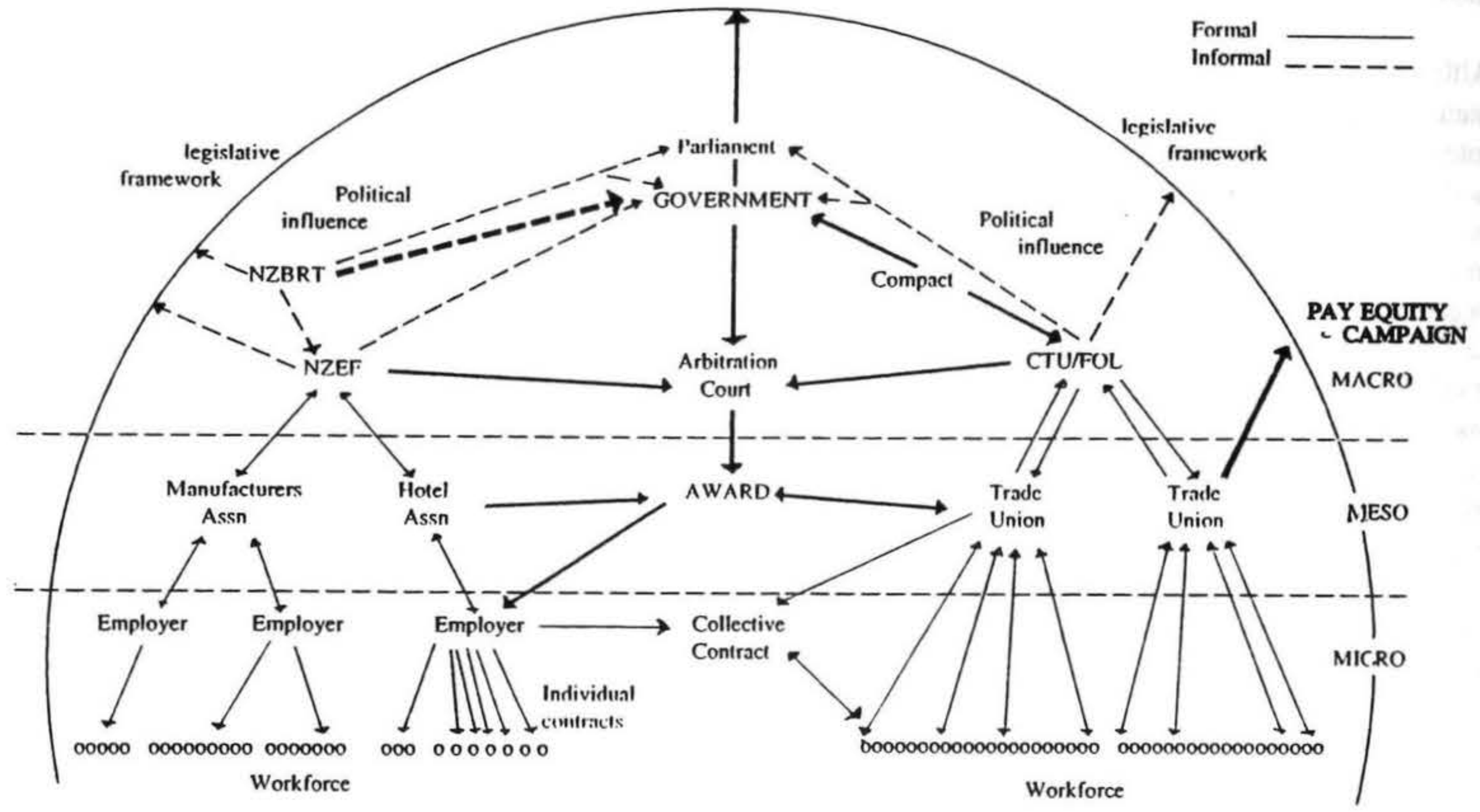

ing labour relations framework in New Zealand. It also indicates the importance of that legislative framework in any consideration of the interests and strategies of both individual unions and the union movement as a whole. As Pat Walsh comments:

Just as the unequal conflict between labour and capital, and the particular form it takes in each society, shape the State's industrial relations policies...the relationship between unions and employers unfolds in the context of the institutional structure of the State's industrial relations policies (Walsh 1993:174).

However, 'labour' - to take just one of corporatist partners - is not a homogeneous abstraction, but comprises men and women at work in different occupations in the labour market. How relevant are corporatist theories to a consideration of women in the labour market? What are the effects of corporatist change on unions representing predominantly women within a labour market segregated by gender?

\section{Corporatist Theory and Women}

International comparative work on the position of women in the labour market (Ruggie 1984; Rubery 1988) suggests that it is not just labour relations or patterns of corporatism that need to be analysed, but the way other policies - fiscal, family, welfare or education - affect the labour market. Jill Rubery critiques theorists who seek a universal model of behaviour applicable over time or between countries.

One aspect of societies should not be singled out for crosscountry comparisons, as this would obscure the different ways in which parts of a society interrelate...We need to understand the ways in which the system of industrial, labour market and family organisation interrelate and the role of the society's political and social values in maintaining these relationships before we could expect to make sense of the differences between countries (Rubery 1988:253).

Nevertheless, on comparing studies from the United States, United Kingdom, France and Italy, Rubery recognises the importance of different systems of labour market organisation and regulation in explaining cross-national differences in levels of male and female pay and in rates of change.

To understand how job segregation acts to exclude women from higher paying iobs, one has to know the relevant divisions within the economy between 'good' and 'bad' employment positions. The form of these divisions is likely to be related to the pattem of collective bargaining and labour market regulation (Rubery 1988:257).

Underlying studies of corporatism are assumptions about patterns of regulation which reflect the norms of the countries examined. Union organisation originated in 
Europe as forms of closure around traditionally male crafts, which provided the labour for key industries as capitalism developed. 'Industrial relations' is aptly named in these countries since organised labour has primarily developed within industrial production sectors, with more recent organisation among state employees. Varying amounts of state regulation of low paid service work in the private sector have occurred as an extension of this. The fact that this seldom involves union organisation and representation, as well as state control, goes largely unremarked by researchers and theorists. Yet this is the core of the 'secondary' labour market in which workers are most disadvantaged and in which women and ethnic minorities are concentrated (Doering \& Priore 1971; Barron \& Norris 1976; Bowie 1983). If the labour market outcomes for marginalised social groups are to be changed, the norms of labour relations bargaining and state regulation need to be problematised, not merely assumed.

To take up Wassenberg's argument that corporatism displaces conflict to other levels, it may be suggested that successful organisation and representation in industry displaces some of the flexibility needs of capitalism into 'unorganisable' sections of the labour market. A British example is the way parttime employment for less than 16 hours is expressly excluded from employment security protections and employer liability for various taxes and deductions (Beechey 1987; Walby 1986:226-27). The result is a higher proportion of low paid women in parttime employment in Britain than in neighbouring countries or in New Zealand (Rubery 1988:262-266). Such an argument implicates the state and labour, as well as capital, in the maintenance of a 'secondary' labour market.

In New Zealand and Australia the regulation of wage bargaining took a distinctively different tack from the European one, and one which facilitated high levels of unionisation among women. Although most New Zealand labour history focuses on the corporatist trade-off between the right to strike and the right to state arbitration, a key difference from European and the United States has been regulation at the level of occupational markets, rather than industries or firms. Awards with blanket coverage and compulsory unionism gave unions a form of occupational closure. Access to arbitration allowed unions with little industrial strength to negotiate effectively in their particular section of the labour market.

The system supported union representation for women in low paid service occupations, which are not unionised in most industrialised countries. My case studies of unions covering clerical work, nursing and cleaning document the logistics of organising small scattered worksites, lack of industrial leverage and personal vulnerability that are typical of women's low paid service work, as well as the moral constraints which undermine industrial action in the main professions for women. Occupational awards institutionalised differences between women's and men's pay rates; nevertheless, high union representation and minimum wage rates have meant a smaller gender pay gap in
New Zealand than in most OECD countries (Hyman 1994:124-136).

When the Employment Contract Bill was introduced, I was engaged in research on feminism and unionism. The new Act meant a unique opportunity to study two markedly different labour relations regimes within the context of a single country. Other factors affecting the position of women, pointed to by Rubery, remained relatively constant, with the National government following similar, if tighter policies in other areas to those under Labour (NACEW 1990: Briar, Munford \& Nash 1992).

The Employment Contracts Act 1991 shifted the basis of bargaining from occupation to enterprise - a system closer the United States pattern rather than the macro-corporatist Swedish one (Boxall 1990). In the United States, the low paid service jobs typically held by women and ethnic minorities are seldom unionised. In 1989, for example, only $13 \%$ of women (and $20 \%$ of men) were unionised in the United States (Crain 1991:1157) and many women in low paid service jobs (and their children) are living below the official poverty line (Scott 1986). In contrast, in 1990 $60 \%$ of all New Zealand employees were covered by wage awards and $40 \%$ were union members, in roughly equal numbers for women and men (Brosnan, Smith \& Walsh 1990: 101).

In my view, New Zealand women benefited from the traditional state supports to unionisation and bargaining by workers in scattered worksites and jobs which lacked industrial leverage. They also benefitted from union organisation which reflected the gendered structure of the labour market, meaning that women were organised into large unions with female dominated memberships.

Women became more active in unionism from the mid1970s. By 1991 the number in paid and unpaid positions of union responsibility had greatly increased (PSA 1976; Geare, Herd \& Howells 1979; Sarr, 1992). The most strongly female-dominated had women as union secretaries and presidents. These leaders aimed to make union membership more relevant to women by prioritising parental leave, sexual harassment, pay equity and equal employment opportunity - all issues which addresssed women's labour market disadvantage. These issues were raised in cross-union women's committees, and in forums within the 'labour' corporation. Most progress was made, however, in the political arena, through wide based campaigns to changed the corporatist bargaining framework to include these issues (Dann 1985; Wilson 1992; CEVEP 1994).

\section{Conflicting Demands for Flexibility}

In the 1980 s institutionalised bargaining at the meso level came under pressure from different, contradictory demands for change and greater 'flexibility' - not only from 'capital', but from different sections of 'labour'. 
Women unionists were campaigning to extend the content of award negotiations to include issues related to gender at work and in the labour market. Some unions had been blocked from negotiating over the introduction of new technology and health and safety issues, and a procedure for 'new matters' was included in the Labour relations Act, 1987. The 1987 Act also included discrimination and sexual harassment as grounds for personal grievance procedures. The State Sector Act, 1988 required government departments to implement equal employment opportunity programmes. The Employment Equity Act, 1990 extended this requirement to large private sector employers and introduced procedures for employment equity assessments between male- and female-dominated occupations for incorporation into award negotiations.

A longstanding tension between sections of 'labour' has been between those unions who benefited from state arbitration and those unions who at times felt they would do better to rely on industrial muscle - with most unions representing private sector female dominated occupations in the first group. Economic recession, government invention in wage rounds and wages rates falling against inflation led these unions and Federation of Labour leaders to seek greater flexibility in the right to strike. Their position contributed to the removal of the right to arbitration on award negotiations through legislative changes in 1984 and 1987 (Walsh 1989: 155).

In 1989, without the backup of arbitration, award talks covering clerical workers, licenced hotel clerical workers, licenced hotel workers, tearoom and restaurant workers and a number of smaller awards broke down for over a year. These awards covered around third of all unionised women workers and presaged the gendered effects of the Employment Contracts Act, 1991.

The main drive for 'flexibility' came from the New Zealand Business Roundtable (NZBRT), the lobby group representing large capital. Smaller employers reported relative satisfaction with centralised bargaining (McAndrew \& Hursthouse 1991, 1992). The Business Roundtable argued that bargaining reform would enable the labour market to respond efficiently to the changing needs of expanding and contracting industries. Flexibility in industry development was conflated with demands for greater flexibility from the 'over-priced' New Zealand worker (NZBRT 1987, 1988, 1990). While feminists argued that women's skills were systematically undervalued, free market advocates were suggesting that greater 'flexibility' would allow 'disadvantaged' Maori, Pacific Island and women workers to price themselves into a job (Brook 1990:76; NZ Treasury 1987:279). The Business Roundtable considered that labour market inefficiency and 'rigidity' resulted from minimum award rates, arbitration, compulsory unionism, set hours of work and penal payments. These were just the mechanisms developed during previous Depressions to support and protect industrially weak groups of workers (Simpson 1987), particu- larly women.

The Business Roundtable's agenda for labour market 'reform' was adopted first by the Employers Federation, then the National government (Herbert 1990; Roper 1993; Walsh \& Ryan 1993:15). In corporatist terms, a shift in the interests of large 'capital', supported by 'the state' - itself a large employer - led to employers' withdrawal from the meso-level 'historic compromise' with 'labour' at the meso level of institutionalised wage bargaining. But leaders of 'labour' had been strategising their own changes to the pattern of corporatism.

\section{'Strategic Unionism': Corporatism and the NZCTU}

As redundancies in industry and the state impacted on traditionally strong unions, NZCTU leaders began to emphasise job retention, economic growth and influence on government policy, rather than industrial action. Rather than focusing on 'acts of symbolic polarisation' at the macro level (Wassenberg 1982:85), NZCTU leaders expressed greater interest in and responsibility for economic growth (Campbell \& Kirk 1983; Harris 1991, 1993).

The modern industrial state...had to develop and often manage the infrastructure...A role for unions slots into that type of balanced, sovereign nation state (NZCTU 1991:3).

To balance the influence of the Business Roundtable, NZCTU leaders sought to formalise this role at the macro level through a Compact with the Labour government providing greater consultation and union input into policy matters (NZCTU 1988, 1990; NZ Govt 1989; TUEA 1989).

Tripartite agreements are a hybrid form linking corporatism and parliamentarism (Jessop 1982:195), but the Compact was never more than bipartite. It was primarily a strategy to realign the policies of labour movement and Labour government. In fact, it originated with the 'corporatist tendency' within the Labour caucus and Labour Party which had been defeated by Labour's free market Ministers (Oliver 1989), but which began to gather strength in Labour's second term.

NZCTU officials were strongly influenced by the Australian Accord between unions and the Labour government, borrowing the phrase 'strategic unionism' for their own Compact strategy (ACTU/TDC 1987; Willis 1985). Both Accord and Compact drew on corporatist models of considerable historic success from Austria, Germany and Scandinavia. European models proposal in both countries to restructure the union movement on industry or sector lines, rather than occupations. By the late 1980 s, however, corporatism was beginning to crack in Europe, with slashed welfare in Sweden and state sector strikes in Germany in the early 1990s. In Australia the Accord and union restructuring were also drawing criticism from sections of 
the labour movement and from feminists as of little benefit to women workers (Ross, O'Lincoln \& Willett 1986; Tanner 1989; NZCWA 1989; Windsor 1990; Pringle \& Watson 1992:60).

In New Zealand some dissent to 'strategic unionism' reflected a view of corporatism as collaboration (Harvey 1992). But other unionists objected to the undemocratic way the vaguely worded Compact, then Growth Agreement, was implemented. Also the Growth Agreement reimposed centralised control of the wage round for little concrete return. Some unions for female dominated occupations considered its 'productivity' component ill-conceived for service work.

An integral strand of NZCTU strategy was restructuring the 'labour' corporation by industry, then sector (Harvey 1992:66; NZCTU 1988, 1989) - 'because that is how the economy works' (Easton 1990; Hill 1991). An industrybased structure would amalgamate some small male craft unions into larger units and might facilitate union input into industry development. However, it would fragment negotiations covering labour markets which spanned industries, splitting some large unions for female dominated occupations. The NZCTU estimated, in response to criticism, that three of its 14 proposed sector unions would have memberships with a female majority of about $65 \%$. However, the few unions with a woman as union secretary have female majorities of $85 \%$ or more.

The NZCTU's proposal for industry based unionism follows the pattern of the countries from which its corporatist models were drawn. However, OECD countries have greatly varying rates of female unionisation, and union organisational structures in which women are underrepresented have attracted criticism (Cockburn 1984; Milkman 1985; Crain 1991; Cobble 1991; ILO 1988; ICFTU 1991). The papers of the Labour/NZCTU Compact Committee reflected no analysis of this, nor of New Zealand's own very different arrangements. (Nor do NZCTU Compact publications mention the other macro level strategy of the time, the campaign for legislation to reassess the value of women's work.)

In terms of corporatist theory, what the Compact required from unions was a more tightly organised structure which could deliver on decisions made by national leaders - that is, a structure designed to control as well as represent. A future tripartite Compact would require similarly tight organisation among employers. $^{2}$

Following the 1990 election National declined continuing the Compact. However, the themes of bipartite corporatism, union restructuring and industrial action rather than arbitration continue to shape NZCTU strategies. In part, this reflects greatly weakened representation by unions for whom large scattered labour markets are more important than specific industries. It was these unions, and unions for female dominated occupations in particular, that bore the brunt of bargaining 'reform'.

\section{The gendered impact of the Employment Con- tracts Act}

The National government rapidly implemented most of the Roundtable agenda for labour market reform through the Employment Contracts Act, the repeal of the Employment Equity Act and cuts to benefit payments.

In corporatist terms, the Employment Contracts Act dismantled institutionalised arrangements at the meso level, fragmenting awards into thousands of enterprise negotiation (Hill \& Du Plessis 19933. Also at the macro level, the recent extensions of the bargaining framework to allow gender and race inequalities to be addressed were also dismantled.

By September 1992, 45\% fewer employees had dropped from coverage by collective documents, with most of these in small private sector firms (Harbridge 1993:46). Microlevel bargaining disproportionately decollectivised and deunionised women in private sector clerical, sales and service work (Sarr 1993; Hammer \& Harbridge 1993; Hill \& Du Plessis 1993). The Services Workers Union reported a 32\% drop in membership; the Distribution \& General Workers Union around 30\%. The northern and southern clerical unions dropped $45 \%$ and amalgamated with the Service Workers Union, while the union covering clerical workers from Taupo to Dunedin was dissolved, with some members distributed to industry unions under the auspices of the NZCTU. The Amalgamated Workers Union, covering scattered, casualised but predominantly male iobs, suffered similar losses. Union membership in the state sector remained high, with nurses in both public and private health taking strike action around the country.

Women's loss of collective bargaining power and an attack on penal rates in health and hospitality were reflected in a widening of the gender pay gap by early 1993 , the year following the expiry of most awards (NZ Statistics 1993).

By 1993 deunionisation and amalgamations had also affected women's representation in union leadership, with fewer union secretaries or presidents representing fewer women members (Sarr 1993). With the number of contract negotiations and individual grievances dramatically increased, even women-led unions are giving less attention to issues like employment equity, although this is by no means off the political agenda.

\section{Between Corporatism and Parliamentarism}

The corporatist theoretical model (figures 1 and 2) can facilitate consideration of the changes in New Zealand's labour relations system and about how these have come about achieved. Claus Offe and H. Wissenthal (1985:202) have argued class struggle involves struggle about politi- 
cal forms as well as within political forms, and New Zealand labour history shows that this is equally true of labour relations. The interests of 'capital', 'the state' and 'the unions' are pursued both within the institutional forums for wage negotiations and in other arenas in which the struggle is about the forms those institutions should take.

The legislative changes of the $1980 \mathrm{~s}$ and 1990 s were made through the political system of representation and control, but the political manoeuvring which led to the various changes occurred in the spaces between the political system and the corporatist framework for labour relations negotiations (figure 1). 'Labour' and one group within politics initiated a formal corporatist arrangement - the Compact - which was short lived. In this particular economic recession 'capital' and political groups aligned with it did not see their interests as lying in corporatist compromises - its goals were already being successfully achieved by informal means and its agenda implemented through government policy and legislation. Particularly interesting was the extent of appointments of individuals representing the interests of 'capital' to positions managing the restructuring of the state's delivery/control system (TUEA 1987).

Links between the parliamentary system and the corporations of labour and capital at the macro level have been formalised through tripartite agreements in some European countries. However, these need to be analysed within the specific pattern of labour market regulation, with an eye to whether these protect and empower all sections of the workforce. Events in Sweden and Germany illustrate the fact that all corporatist arrangements are strategies within particular economic contexts and are historically contingent.

In New Zealand tripartite talks occurred intermittently between the early 1970 s and early 1980 s, with little success. As Lehmbruch (1982:24) observes, forms of corporatism in which contact is restricted to leaders at the top of autonomous hierarchies retain the option of a low cost 'exit' - by discontinuing talks or as in 1990 by a change of government. This contrasts with the stability of the meso level award system, which brought unions and employers firmly into a system of negotiation.

Although the NZBRT denounced award bargaining as inflexible, changes in the 1970s and 1980s had amended the traditional system to allow direct bargaining, enterprise and industry documents as well as occupational ones, and a wider range of issues. Without government intervention and without access to compulsory arbitration removed, a wider range of wage rate outcomes began to emerge (Harbridge 1990). In 1990 both the Clerical Workers Unions and the New Zealand Nurses Association were complaining that their rates had slipped against the core male trades. However, the legislative framework had been widened to include parental leave, sexual harassment, equal employment opportunity and (briefly) pay equity. These changes benefitting women had been raised within the 'corporation' of labour, but pursued through the political system to change some of the rules for meso corporatist bargaining.

In the 1980 s greater progress was made on gender issues in New Zealand than in other OECD countries. Occupational unionism led to female-dominated women-led organisations which prioritised these issues. These changes were not initiated by leaders at the macro-level; nor is it likely that such issues would be raised by industry-based unions, which would have lower proportions of female members and be less likely to be achieve women leaders.

While men's employment is typically patterned by industry, the markets for women's skills often span industries for example, cleaning, customer service and especially clerical work. Women's labour market disadvantage operates through and is much more marked by occupation than by industry groupings. However, in New Zealand in the 1970 s and 1980 s union organisation reflecting gendered occupations provided the numerical strength to pursue common interests among women workers, facilitating the development of a distinctively feminist unionism.

My own view is that bargaining at the meso level by occupation has potential to combine both worker protection and flexibility of content. Meso level bargaining by occupation provides the collective strengthen to allow meaningful bargaining by women in scattered service work, which is now being deunionised. The gendered and racially segregated nature of the labour market is more marked by occupation than by industry, since it is through the gender- or race-typing of jobs that earnings differentials are organised (Cockburn 1985; Walby 1988; NACEW 1990). Bargaining by occupation is more relevant than by industry for those with general skills, who are most in need of labour market protections. Bargaining by occupation also allows workers to organise around common concerns - not just overtly gender-specific ones like sexual harassment, but also casualisation and changes to work hours, health hazards and professional issues. A more relevant, voluntary unionism needs not only to address 'the entire spectrum of needs that people have when they are employed as wage workers' (Offe \& Wissenthal 1985:179), but to build solidarity around commonalities of interest among specific groups.

\section{Conclusion}

The Employment Contracts Act introduced a radical change to corporatist arrangements in New Zealand, shifting wage negotiation from the meso to the micro level. This has disproportionately deunionised women in sales, clerical and service work (Sarr 1993). Yet these are...

...the prototypic worker(s) of the post-industrial era...the workers to whom organised labour must now appeal if it is survive. (Cobble 1991:76).

Labour relations legislation and a union movement which 
can disregard the decollectivisation of this section of the workforce as 'unorganisable' needs to address...

...fundamental questions about the definitions of work, collective organisation and collective action, labour power and the structure of labour law itself. (Crain 1991:1158)

My objective in this paper has been to share and critique a theoretical framework which may be of assistance in this.

\section{Future Research}

Patterns of corporatism are outcomes of political agendas and political struggles. But an important contribution to these can be made by research agendas which inform the process of policy making. So far, there has been analysis and critique at the level of politics and economics, and research findings are coming through which show the outcomes of collective negotiations and changes to levels of unionisation under the new legislative regime.

But the philosophy behind the Act values individual freedoms, not collective ones. Along with freedom of association, the Act introduced the 'option' of an individual employment contract for all employees. Where is the research investigating outcomes of individual employment contract negotiations? Exactly what happened to the estimated 336,000 workers who had dropped from collective coverage by September 1993 (Harbridge 1993:46) and the women in sales, clerical and service work who are no longer represented by a union (Sarr 1993) It's time we found the resources and the research design to take that one out of the 'too hard' basket.

\section{Notes}

1. This draws on arguments from my doctoral thesis, Feminism \& Unionism in NZ: Organising the Markets for Women's Work, University of Canterbury, 1994. Case studies of unions covering clerical work, nursing and cleaning document differences of position and strategy in relation to mainstream unionism and legislative changes.

2. The change to enterprise contracts removed award talks as a focus for collective organisation among employers. However, in 1992 the bargaining strategies recommended to employers by most industry associations were in line with Employers Federation/ Business Roundtable philosophy.

\section{References}

ACTU/TDC 1987 Australia Reconstructed: ACTU/TDC Missions to Western Europe. Canberra: Australian Government Publications.

Beechey, Veronica. 1987 'Conceptualising Part-time Work'. In Beechey, Unequal Work, 149-168. London: Verso
Boxall, Peter 1991 'NZ's Employment Contracts Act 1991: An Analysis of Background, Provisions and Implications'. Australian Bulletin of Labour, 17

Bowie, J. R. 1983 'The Dual Labour Market'. In Brian Easton (ed) Studies in the Labour Market. Wellington: NZIER

Briar, Celia, Robyn Munford \& Mary Nash (eds) 1992 Superwoman, Where Are You? Social Policy and Women's Experience.Palmerston North:Dunmore Press

Brook, Penelope 1990 Freedom at Work. Auckland: Oxford University Press

Brosnan, Peter, Pat Walsh \& P. Rowe 1985 'The Inactivities of Employer Unions'. NZ Journal of Industrial Relations 10: 1411-56

Brosnan, Peter, David Smith \& Pat Walsh 1990 The Dynamics of NZ Industrial Relations. Auckland: John Wiley

Campbell, Rob \& Alf Kirk 1983 After the Freeze: NZ Unions in the Economy. Wellington: Port Nicholson Press

Coalition for Equal Value Equal Pay 1993 Just Wages: History of the Campaign for Pay Equity 19841993. Wellington: CEVEP

Crain, Marion 1991 'Feminising Unions: Challenging the Gendered Structure of Wage Labor'. Michigan Law Review 89: 1155-1221

Dann, Christine 1985 Up From Under: Women and Liberation in NZ: 1970-1985. Wellington: Allen \& Unwin

Easton, Brian 1990 Lecture to Workers Education Assn, Christchurch

Goldfinch, Shaun \& Brian Roper 1993 'Treasury's Role in State Policy Formulation in the Post-War Era'. In Brian Roper \& Chris Rudd (eds) State and Economy in NZ, 50-73. Auckland: Oxford University Press

Hammond, Suzanne \& Raymond Harbridge 1993 'The Impact of the Employment Contracts Act on Women at Work'.NZ Journal of Industrial Relations 13(1)

Raymond Harbridge 1990 'Flexibility in Collective Wage Bargaining in NZ: Facts \& Folklore'. NZ Journal of Industrial Relations 15(3): 241-250

Raymond Harbridge (ed) 1993 Employment Contracts: $N Z$ Experiences. Wellington: Victoria University Press 
Harris, Peter 1991 'Reshaping the Economic Agenda'. Papers of the Union/Tertiary Research Conference, Wellington

Harris, Peter 1993 'Industry Policy: A Key to Jobs and Job Security'. Wellington: NZCTU

Harvey, Owen 1992 'The Unions and the Government: The Rise and Fall of the Compact'. In John Deeks \& Nick Perry, Controlling Interests: Business, the State and Society in NZ, 59-77. Auckland: Auckland University Press

Herbert, Patricia 1990 'Coup in Employers Group Brings Shift Rightwards'. The Press, 30 March

Hill, Linda 1991 'Labour Market Segregation and the Case for Occupational Unions - Part I: Organising Labour Market Segments; Part II: The Case Against Industry Unionism'. Unpublished paper

Hill, Linda \& Rosemary Du Plessis 1993 'Tracing the Similarities, Identifying the Differences: Women and the Employment Contracts Act'. NZ Journal of Industrial Relations 18(1): 31-43

Holt, James 1986 Compulsory Arbitration in NZ: The First Forty Years.. Auckland: Auckland University Press

International Confederation of Free Trade Unions 1992 Equality: The Continuing Challenge - Strategies for Success. Brussels, ICFTU

International Labour Organisation 1988 Women at Work, 2, Geneva

Jesson, Bruce 1987 Behind the Mirror Glass. Auckland: Penguin

Jessop, Bob 1979 'Corporatism, Parliamentarism and Social Democracy'. In Philippe C. Schmitter \& Gerhard Lehmbruch (eds) Trends Toward Corporatist Intermediation, 185-211.London: Sage Lehmbruch, Gerhard \& Philippe C. Schmitter (1982) Patterns of Corporatist Policy-Making. London: Sage

McAndrew, Ian \& Paul Hursthouse 1990 'Southem Employers on Enterprise Bargaining', NZ Journal of Industrial Relations 15(2) 117-128

McAndrew, Ian \& Paul Hursthouse 1991 'Reforming Labour Relations: What Southern Employers Say'. NZ Journal of Industrial Relations 16(1): 1-12

Milkman, Ruth 1985 'Women Workers, Feminism and the Labor Movement since the 1960s'. In Milkman (ed) Women, Work and Protest: A Century of VS Women's Labour Movement, 300-319. London:
Routledge \& Kegan Paul

Mulgan, Margaret 1993 'Women at Work: Ensuring Equity in the Employment Relationship: The Case for a Minimum Code' NZ Journal of Industrial Relations 18(1): 9-14

National Advisory Council on the Employment of Women 1990 Beyond the Barriers: The State, the Economy and Employment, 1984-90. Wellington NACEW/Dept of Labour

NZ Council of Trade Unions 1988 The Need for Change: Challenges for the Trade Union Movement of Today. Wellington: NZCTU

NZ Council of Trade Unions 1989 Strategiesfor Change: Challenges for the Trade Union Movement of Today. Wellington: NZCTU

NZ Council of Trade Unions 1990 'The Compact and the Direction of Economic Policy’. March 1990

NZ Government/NZCTU 1989 'The Compact: Statement by the Government and the NZCTU'. December

NZ Clerical Workers Association 1989 The Australian Accord and the NZCompact. Wellington: NZCWA

NZ Treasury 1987 Government Management: Brief to the Incoming Government. Wellington: GP

Offe, Claus \& H. Wissenthal 1985 'Two Logics of Collective Action'. In Offe, Disorganised Capitalism: Contemporary Transformations of Work and Politics, 170-220. Cambridge, Mass: MIT Press

Oliver, W. Hugh 1989 'The Labour Caucus and Economic Policy Formation, 1981-84'. In Brian Easton (ed) The Making of Rogernomics, 11-52. Auckland: Auckland University Press

Pringle, Rosemary \& Sophie Watson 1992 “'Women's Interests" and the Post Structuralist State'. In Michelle Barrett \& Anne Phillips, Destabilising Theory: Contemporary Feminist Debates, 53-73. Cambridge: Polity Press

Regini, Marino 1982 'Changing Relations between Labour and the State in Italy: Towards a Neocorporatist System'. In G. Lehnbruch \& P. C. Schmitter, Patterns of Corporatist Policy-Making, 109-130. London: Sage

Roper, Brian 1983 'A Level Playing Field? Business Political Activism and State Policy Formation'. In Brian Roper \& Chris Rudd (eds) State and Economy in New Zealand 147-171. Auckland: Oxford University Press 
Ross, Liz, Tom O'Lincoln \& Graham Willett 1986 Labour Accord: Why it's a Fraud. Brunswick, Vic: Socialist Action

Rubery, Jill 1988 Womenin Recession.London: Routledge \& Kegan Paul

Ruggie, Mary 1984 The State and Working Women: A Comparative Study of Britain and Sweden.Princeton University Press

Ryan, Rose \& Pat Walsh 1983 'Common Law versus Labour Law: The NZ Debate'. Paper to Industrial Relations Conference, Auckland, January

Sarr, Patricia 1992 Out of the Chorus Line: The Progress of Women in NZ Unions. Wellington: NZCTU

Sarr, Patricia 1993 Shifting Sands: Women in NZUnions 1993. Wellington, NZCTU

Schmitter, Philippe C. \& Gerhard Lehmbruch (eds) 1979 Trends Toward Corporatist Intermediation. London: Sage

Scott, Hilda 1986 Working Your Way to the Bottom: The Feminisation of Poverty. Boston: Pandora

Simpson, Tony 1987 'The Holt Narrative and the Industrial Relations Agenda', NZ Journal of Industrial Relations 12 143-150

Simpson, Tony 1990 The Slump: The Thirties Depression, Its Origins and Aftermath. Auckland: Penguin

Skinner, Sir Tom 1980 Man to Man. Auckland: Whitcoulls, 1980: see also Obituary, NZ Herald, 13 November 1991

Statistics NZ 1993 'Hot Off the Press - Quarterly Employment Survey: February and May/June

Strinati, Dominic 1991 'A Ghost in the Machine? The State and the Labour Process in Theory and Practice'. In D. Knight \& H. Willmott (eds) Labour Process Theory, 209-243. Basingstoke: Macmillan

Taylor, Raymond \& Bevan Greenslade 1986 'The Activity of Employer Unions in Perspective', and Peter Brosnan \& Pat Walsh, 'Reply to Taylor \& Greenslade', NZ Journal of Industrial Relations 11: $191-192$

Trade Union Education Authority 1987 'The Business Roundtable'

Trade Union Education Authority c.1989 'Compact Resource Kit', undated
Vowles, Jack 1985 'Business \& Labour. Major Organised Interests in the Political Economy of NZ'. In Hyam Gold (ed) NZ Politics in Perspective, 216-231. Auckland: Longman Paul

Walby, Sylvia 1986 Patriarchy at Work. Cambridge: Polity Press

Walby, Sylvia (ed) 1988 Gender Segregation at Work. Milton Keynes: Open University Press

Walsh, Pat 1989 'A Family Fight? Industrial Relations Reform Under the Fourth Labour Govemment'. In Brian Easton (ed) The Making of Rogernomics, 149-170. Auckland University Press

Walsh, Pat 1993 'The State and Industrial Relations in NZ'. In Brian Roper (ed) State and Economy in New Zealand 1-25. Auckland: Oxford University Press

Wanna, John 1989 'Centralisation Without Corporatism: The Politics of NZ Business in Recession', NZ Journal of Industrial Relations 14: 1-15

Wassenberg, Arthur 1982 'Neo-Corporatism and the Quest for Control: The Cuckoo Game'. In Gerhard Lehmbruch \& Philippe C. Schmitter, Patterns of Corporatist Policy-Making, 83-107.London, Sage

Willis, Ralph c. 1985 Accord: The First Two Years. Canberra: Ministry of Employment and Industrial Relations

Wilson, Margaret 1992 'Employment Equity Act 1990: A Case Study in Women's Political Influence, 1984-90'. In John Deeks \& Nick Perry, Controlling Interests: Business, the State and Society in New Zealand, 113-131. Auckland: Auckland University Press

Windsor, Kim 1990 'Making Industry Work for Women'. In Sophie Watson (ed) Playing the State: Australian Feminist Interventions, 137-151.London:Verso

Author

Linda Hill is a PhD student in the Department of Sociology at the University of Canterbury, Private Bag 4800 , Christchurch. 